\author{
Working Paper 78-3 \\ REQUIRED RESERVES, CORRESPONDENT BALANCES AND CASH ASSET \\ POSITIONS OF MEMBER AND NONMEMBER BANKS: \\ EVIDENCE FROM THE FIFTH FEDERAL RESERVE DISTRICT
}

Bruce J. Summers

Federal Reserve Bank of Richmond

April 1978

The views expressed here are solely those of the author and do not necessarily reflect the views of the Federal Reserve Bank of Richmond. John Segala provided valuable research assistance for this study. 


\section{REQUIRED RESERVES, CORRESPONDENT BALANCES AND CASH ASSET POSITIONS OF MEMBER AND NONMEMBER BANKS: \\ EVIDENCE FROM THE FIFTH FEDERAL RESERVE DISTRICT}

\section{Bruce J. Summers}

\section{Introduction}

Increasing membership attrition has stimulated research into the costs and benefits of Federal Reserve System membership compared to the nonmembership alternative. Recent research has contributed to our understanding of the membership question in two important ways. First, the nature of the costs and benefits of membership and of the nonmembership altemative has been substantially clarifled. As a result, the criteria that determine the cost of membership compared to nonmembership are better defined. Second, these criterla have been applied in attempts to measure the degree of the comparative costs of membership. This study attempts to further clarify the definition of the comparative burden of Federal Reserve membership and applies this definition in measuring the comparative costs of membership for smaller commercial banks in the five Fifth Federal Reserve District states. $1 /$

The study has four basic parts. Section II develops a formal measure of the comparative burden of membership based on the opportunity costs to banks of holding a specific array of nonearning cash assets. In Section III, this measure is used to calculate the degree of the relative burden of membership on smaller Fifth District member banks of various sizes. The results from using this asset array are shown to be substantially different than those obtained through analysis of required nonearning asset reserve positions. Section IV examines the effect of utilization of Federal Reserve System services on member and nonmember bank holdings of nonearning cash assets. Conclusions 
are presented in Section $V$.

The outcomes of the tests conducted in Section IV have important implications for the question of membership attrition. If empirical tests show that member bank users of System services hold significantly lower correspondent balances, and therefore lower nonearning assets, than do member nonusers, a case can be made that fuller utilization of Federal Reserve services might allow some members to economize on cash balances. Moreover, if empirical tests show that member banks intensively using System services hold smaller nonearning asset balances than do nonmembers, a case can be made that membership need not entail a burden, as is generally thought. Results opposite to those described above would tend to confirm the argument that Federal Reserve membership necessarily entails a burden taking the form of higher operating cash balances.

\section{Defining the Comparative Membership Burden}

Earlier studies of the effects of Federal Reserve System membership have focused attention on effective reserve requirements as the key factors determining differences in performance between member and nonmember banks. Effective reserve requirements are normally defined as statutory reserve requirements adjusted to exclude that portion of the required reserve that can be held in the form of earning assets. This is the sense of the definition used by Gilbert and Peterson [3], who have classified states according to stringency of effective reserve requirements. Previous research has suggested that differences in member versus nonmember bank performance are largely due to differences in Federal Reserve versus state effective reserve requirements $[3,4,9]$. A natural extension of this conclusion is that in states where member bank effective reserve requirements exceed state effective reserve requirements, performance differences are in effect institutionalized. Assuming all banks are 
cash mintmizers, members of the Federal Reserve System must necessarily hold greater proportions of noneaming assets than nonmembers.

As normally understood, however, effective reserve requirements often give an unclear picture of actual reserves required. For example, as commonly used, effective reserve requirements ignore adjustment of total deposits for such things as CIPC, due from balances, and government deposits. Moreover, it is difficult to make any generalizations about the effects of legally specified adjustments to the deposit base subject to reserve requirements. This is due to the fact that the mix of demand and time deposits may vary considerably among banks of varying sizes within states. Deposit mix may also vary considerably among states. This complicates any attempt to classify states according to reserve stringency based simply on an inspection of effective reserve requirements. Another, more serious, drawback of relying on effective reserve requirements as guidelines to membership burdens is that banks' actual cash positions differ considerably from required reserve positions. For example, recent studies have shown that cash assets required for meeting reserves have little influence on total cash assets held by nonmember banks $[6,8]$. The reason for this is that operating cash balances exceed the minimum specified by statutory reserve requirements. Correspondent balances and vault cash are both held for operating purposes and play an important part in determining member and nonmember banks' actual cash asset positions. The focus of current research has shifted away from exclusive consideration of legal or effective reserve requirements and toward the broader determinants of actual cash positions [7].

Given certain assumptions about bank behavior, it is possible to develop a simple yet reasonable framework for describing the comparative burden of membership versus nonmembership based on revealed preference. Such a framework can also be modified to yield a measure of the degree to which reserve assets held 
by member banks satisfy correspondent service requirements. A key advantage of using an approach based on revealed preference is that the description of the comparative burden is estimable using observable variables.

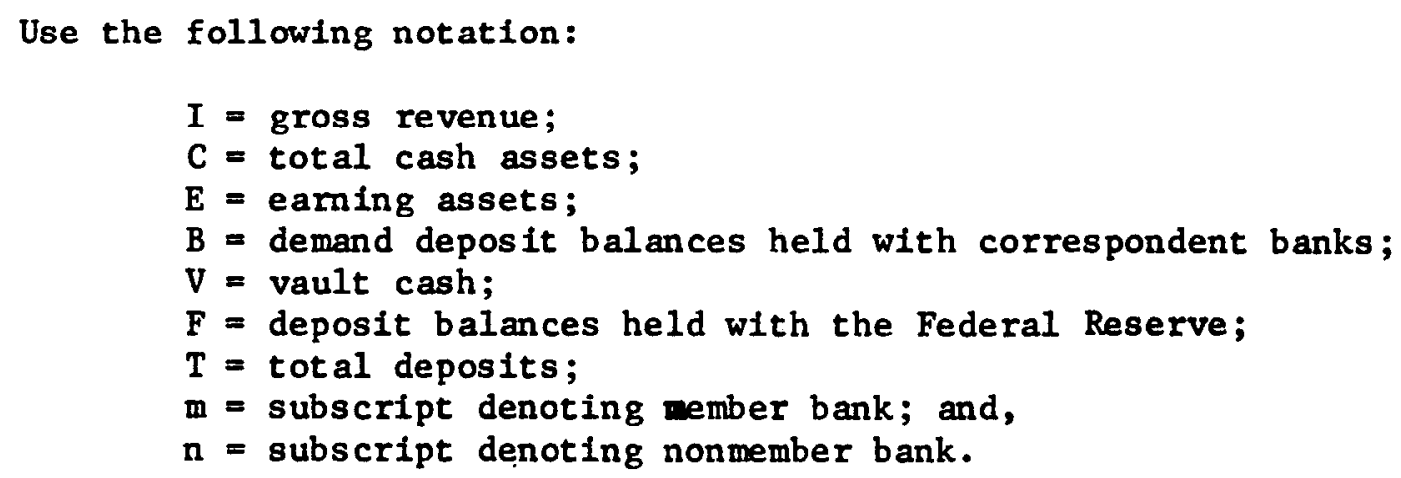

An important objective of commercial banks is to maximize revenue. This objective is attained when available funds are optimally distributed between cash assets and eaming assets. In its simplest form, the commercial bank revenue function can be expressed as

$$
I=f(C, E) \text {. }
$$

One approach to finding the optimal asset $\mathrm{mix}$ is to $t$ reat $\mathrm{E}$ as a residual and minimize $C$ subject to relevant legal and operational constraints. The assumption that banks in fact attempt to minimize nonearning assets subject to certain constraints is central to the discussion that follows.

Assume there are two commercial banks (or groups of commercial banks) identical with respect to size, location, and deposit composition, but not Federal Reserve membership status. If the composition of earning assets for these banks is identical, an assumption that does not seem too extreme given identical size and location, then there will be no feedback effects from $E$ to $C$. With all their characteristics identical except membership status, the ideally paired comparison banks can also be assumed to have identical demands for correspondent type banking services. The cash assets held by the comparison banks differ somewhat in composition: 


$$
\begin{aligned}
& C_{m}=B+V+F, \text { and } \\
& C_{n}=B+V \cdot \underline{2 l}
\end{aligned}
$$

The member bank holds reserves equal to some proportion, $r_{m}$, of total deposits, and $V$ and $F$ are eligible reserve assets. $r_{m}$ has a constrained minimum equal to the legal reserve ratio, but it may be higher than this minimum depending on the bank's perceived need for excess reserves. Member bank reserve requirements are binding; that is, the amount of cash assets held for meeting reserves raises the total amount of cash assets held. The nonmember bank holds reserves equal to the proportion $r_{n}$ of total deposits, and $V$ and $B$ are eligible reserve assets. $r_{n}$ also has a constrained minimum, but it may be higher than this minimum. Nonmember bank reserve requirements are nonbinding; that is, the amount of cash assets held for meeting reserves does not raise the total amount of cash assets heId.

Both member and nonmember banks require correspondent type services to support thelr activity. Member banks have access to correspondent services from two sources, the Federal Reserve and correspondent banks. To the extent that a member bank's demand for correspondent services is not met by the Federal Reserve either in terms of variety or quality of services, correspondent balances will be held in some proportion $b_{m}$ to total deposits, or

$$
\text { (1a) } \quad B_{m}=b_{m} T \text {. }
$$

Nonmembers have access to these services from correspondent banks only and hold balances with correspondent banks in the proportion $b_{n}$ to total deposits:

$$
\text { (Ib) } \quad B_{n}=b_{n} T \text {. }
$$

Physical units of money, $V$, are held in some proportion, $v$, to total deposits. Then

$$
\begin{aligned}
& \text { (2a) } v_{m}=v_{m} T \text {, and } \\
& \text { (2b) } v_{n}=v_{n} T \text {. }
\end{aligned}
$$


There are costs to holding V (e.g., accounting costs and security costs) that work to keep currency and coin at the minimum operating requirement for both member and nonmember banks. Since the nonmember reserve requirement is nonbinding, the nonmember bank would necessarily incur an opportunity cost by holding $V$ in excess of the operating minimum. The member bank, however, is under a binding reserve requirement and does not necessarily incur an opportunity cost by holding $V$ in excess of the operating minimum. The member can substitute between $\mathrm{V}$ and $\mathrm{F}$ to meet the legal requirement and may therefore hold vault cash in excess of the operating minimum. Make the assumptions that

$$
v_{m}<r_{m}, v_{n}<r_{n} \text {, and } v_{n} \leq v_{m}
$$

Then to fulfill its perceived reserve need completely, the member bank will hold deposits with the Federal Reserve in residual fashion, or

$$
\text { (3) } F=\left(r_{m}-v_{m}\right) T \text {, where }\left(r_{m}-v_{m}\right)=f_{m} \text {. }
$$

Combining (1a), (2a), and (3) gives

$$
\text { (4a) } C_{m} / T=b_{m}+r_{m} \text {, }
$$

while combining ( $1 \mathrm{~b})$ and $(2 \mathrm{~b})$ gives

$$
\text { (4b) } c_{n} / T=b_{n}+v_{n} \text {. }
$$

Let $c_{m} / T=c_{m}$ and $c_{n} / T=c_{n}$. Accordingly, the comparative burden of membership can be expressed as

$$
\text { (5) } c_{m}-c_{n} \text {, }
$$

or the difference in cash asset to total deposit ratios for banks with all characteristics identical except membership status.

It is clear from the above that differences in member and nonmember bank cash asset ratios are importantly affected by more than actual system reserve requirements. In particular, $b_{m}$ and $b_{n}$ are factors that have attracted much attention in the recent literature. $b_{m}$ is essentially determined by the variety and quality of Federal Reserve services, as well as by the extent to which member 
banks make use of these services. $b_{n}$ is basically a function of nonmember bank correspondent service requirements. Alton Gilbert [2] has attempted to measure the implicit service yleld on member bank reserves using Federal Reserve internal cost data and the implicit yield on correspondent balances using survey data. This approach to measuring service yields on cash assets does not seem appropriate Inasmuch as $\mathrm{it}$ is based on a cost of production theory of value. $3 / \mathrm{Knight}$ [7, p. 24] defines the cost of System membership as

"...the excess of the sum of balances held by member banks at correspondents and the Federal Reserve over balances held by nonmembers at correspondents..."

This definition, which is close to that expressed in equation (5), can be used to derive a measure of the relative service return between units of member bank reservable assets and units of correspondent bank balances, at least for certain classes of member and nonmember banks.

Given that cash balance minimization is an objective, rational behavior calls for a member bank to first meet its service requirements through the Federal Reserve and then to direct any additional requirements to correspondent banks. Assume, therefore, that correspondent balances will be held by a member bank on $1 y$ to the extent necessary to compensate the correspondent bank for services not provided by the Federal Reserve. It is then possible to define

$$
\text { (6) } b_{m}=b_{n}-x\left(r_{m}-v_{n}\right)
$$

where $x$ is the coefficient of relative return between units of member bank reserve assets and units of correspondent bank deposits. (6) assumes that the member bank!s service needs are identical to the service needs of the similar nonmember bank. Accordingly, $b_{n}$ would be the appropriate measure of the member bank's correspondent service needs if no services were provided by the Federal 
Reserve. $v_{n}$ is the best available measure of the minimum ratio of vault cash required for operating purposes. Substituting for $r_{m}$ and rearranging terms, we get

$$
\text { (7) } x=\frac{b_{n}-b_{m}}{f_{m}+\left(v_{m}-v_{n}\right)} \text {. }
$$

Note that all the terms on the right hand side of (7) are empirically observable. The appropriateness of the measure $x$, however, is 11mited to comparisons between member banks that fully use System services and nonmember banks that recelve all of their services from correspondents. Otherwlse, the coefficient of relative return would not measure the service yield on the full array of System services compared to the full array of services obtained through correspondent banks.

Some general conditions can be established for values of $x$, namely:

$$
\begin{aligned}
& x \geq 1 \text { if }\left[f_{m}+\left(v_{m}-v_{n}\right)\right] \leq\left(b_{n}-b_{m}\right) \text {, and } \\
& x<1 \text { if }\left[f_{m}+\left(v_{m}-v_{n}\right)\right]>\left(b_{n}-b_{m}\right) .
\end{aligned}
$$

The meaning of (7) can be 1llustrated using several examples. If $b_{m}=0$ and $\left[f_{m}+\left(v_{m}-v_{n}\right)\right]=b_{n}$, then we conclude that a dollar of member bank reserve assets yields the same service return as does a dollar of correspondent bank balances; in this case $x=1$. If $b_{m}=0$ but $\left[f_{m}+\left(v_{m}-v_{n}\right)\right]>b_{n}$, then $x$ $<1$ and we conclude that a dollar of member bank reserve assets yields only a fraction of the service return yielded by a dollar of correspondent bank balances. Conversely, if $b_{m}=0$ but $\left[f_{m}+\left(v_{m}-v_{n}\right)\right]<b_{n}$, then $x>1$ and we conclude that a dollar of member bank reserve assets yields a greater service return than does a dollar of correspondent bank balances.

\section{Required Reserves and Cash Asset Positions}

The legal and administrative reserve requirements and reserve accounting procedures for the five Fifth District states and the Federal 
Reserve System are catalogued in Table 1. This summary, which covers deposits subject to reserve requirements, reserve requirement ratios, and eligible reserve assets, indicates there is a great deal of variety within the District regarding statutory bank reserve provisions. Two states, Maryland and North Carolina, provide for an adjustment to deposits subject to reserve requirements, as does the Federal Reserve. One state, North Carolina, has graduated reserve ratios. Interest-bearing securities are eligible as part of the required reserve in Maryland and Virginia.

These statutory guldelines are used to compute the required nonearning asset reserve expressed as a percentage of total deposits for four size groupings of member and nonmember banks. The four groups, based on total asset size, are under $\$ 10$ million, $\$ 10-25$ million, $\$ 25-50$ million, and $\$ 50-100$ million. The size groupings contain 334 member and 346 nonmember insured commercial banks as of June 30,1977 . The procedure followed is essentially that used by an individual commercial bank in computing its required reserve, except that in this instance banks of like size have been grouped together. Thus there are forty required nonearning asset reserve ratios ( 5 states $\times 4$ size groups $\times 2$ membership groups). All required nonearning asset ratios are computed for the June 30, 1977 Call Report. Tests reviewed in Appendix A suggest that single day Call Report data such as these can be validly used as proxies for bank behavior averaged over longer time periods.

In Maryland and Virginia, where securities are eligible reserve assets, the legal reserve ratio is adjusted downward using the formula

$$
E R=(1-P) R,
$$

where: $E R=$ effective reserve ratio;

$P$ a proportion of reserves that can be held in earning assets; and, $R$ = statutory reserve requirement.

This assumes that the part of the reserve that can be held in earning asset form imposes no burden at all. 
Table 1

Summary of Legal Reserve Requirements

and Reserve Account ing Procedures

Fifth District States and Federal Reserve System

January 1978

\begin{tabular}{|c|c|c|c|c|c|c|c|c|}
\hline \multirow{2}{*}{ Authority } & \multicolumn{2}{|c|}{$\begin{array}{l}\text { Deposits Subject to } \\
\text { Reserve Requirements }\end{array}$} & \multicolumn{2}{|c|}{ Reserve Requirement Rat 10} & \multicolumn{3}{|c|}{ El1glble Reserve Assets } & \multirow[t]{2}{*}{$\begin{array}{l}\text { Reserve Account Ing } \\
\text { Procedures }\end{array}$} \\
\hline & Demand & Time & Demand & Time & Demand & & Time & \\
\hline Maryland & $\begin{array}{l}\text { Total demand } \\
\text { deposits less } \\
\text { collateralized } \\
\text { deposits of } \\
\text { public funds. }\end{array}$ & $\begin{array}{l}\text { Total time } \\
\text { deposits less } \\
\text { collaterallzed } \\
\text { depostts of } \\
\text { public funds. }\end{array}$ & $15 \%$ & $3 \%$ & $\begin{array}{l}\text { Vault cash } \\
\text { Due from } \\
\text { banks } \\
\text { U.S. Gov. } \\
\text { securities } \\
\text { State of } \\
\text { Md. } \\
\text { securit les } \\
\text { Approved } \\
\text { obliga- } \\
\text { tlons of } \\
\text { Md. munic1- } \\
\text { palities }\end{array}$ & $\begin{array}{l}\text { at least } \\
662 / 3 \% \\
\text { of total } \\
\text { reserve } \\
\text { up to } \\
331 / 3 \% \\
\text { of total } \\
\text { reserve }\end{array}$ & $\begin{array}{l}\text { Vault cash } \\
\text { Due from } \\
\text { banks } \\
\text { U.S. Gov. } \\
\text { secu- } \\
\text { rities } \\
\text { State of } \\
\text { Md. secu- } \\
\text { rities }\end{array}$ & $\begin{array}{l}\text { Contemporaneous } \\
\text { reserve accounting } \\
\text { on a dally basis. } \\
\text { No formal penal- } \\
\text { ties for reserve } \\
\text { deficlencles. }\end{array}$ \\
\hline North Carolina & $\begin{array}{l}\text { Total demand } \\
\text { deposits less } \\
\text { collaterallzed } \\
\text { deposits of } \\
\text { publlc funds. }\end{array}$ & $\begin{array}{l}\text { Total time } \\
\text { deposits } \\
\text { less collat- } \\
\text { erallzed de- } \\
\text { posits of } \\
\text { public funds. }\end{array}$ & $\begin{array}{l}\$ \text { mi111ons } \\
0-2 \ldots \ldots 88 \% \\
2-10 \ldots \ldots 10 \% \\
10-100 \ldots .12 \% \\
100-400 \ldots 13 \% \\
\text { over } 400 \ldots 15 \%\end{array}$ & $\begin{array}{l}\text { savings \& } \\
\text { t1me open } \\
\text { account.....3\% } \\
\text { other time } \\
\text { maturing in } \\
180 \text { day } 8 \\
\text { or more...3\% } \\
\text { maturing in } \\
\text { less than } \\
180 \text { days } \\
0-5 \\
\text { million ...37 } \\
\text { over } 5 \\
\text { million...6\% }\end{array}$ & $\begin{array}{l}\text { Vault cash } \\
\text { Due from } \\
\text { banks } \\
\text { CIPC }\end{array}$ & & $\begin{array}{l}\text { Vault cash } \\
\text { Due f rom } \\
\text { banks } \\
\text { CIPC }\end{array}$ & $\begin{array}{l}\text { Contemporaneous re- } \\
\text { serve accounting } \\
\text { using a dally aver- } \\
\text { age based on a } 14 \text { day } \\
\text { period. No formal } \\
\text { penalties for } \\
\text { reserve deficlencles. }\end{array}$ \\
\hline South Carolina & $\begin{array}{l}\text { Total demand } \\
\text { deposits. }\end{array}$ & $\begin{array}{l}\text { Total time } \\
\text { deposits. }\end{array}$ & $7 \%$ & 37 & $\begin{array}{l}\text { Vault cash } \\
\text { Due from } \\
\text { banks } \\
\text { CIPC with a } \\
\text { standing of } \\
10 \text { days or } \\
\text { less }\end{array}$ & & $\begin{array}{l}\text { Vault cash } \\
\text { Due from } \\
\text { banks } \\
\text { CIPC with a } \\
\text { standing of } \\
\text { lo days or } \\
\text { less }\end{array}$ & $\begin{array}{l}\text { Contemporaneous } \\
\text { reserve accounting } \\
\text { on a daily bas1s. } \\
\text { No formal penalties } \\
\text { for reserve defi- } \\
\text { clencles. }\end{array}$ \\
\hline
\end{tabular}


Table 1, page 2

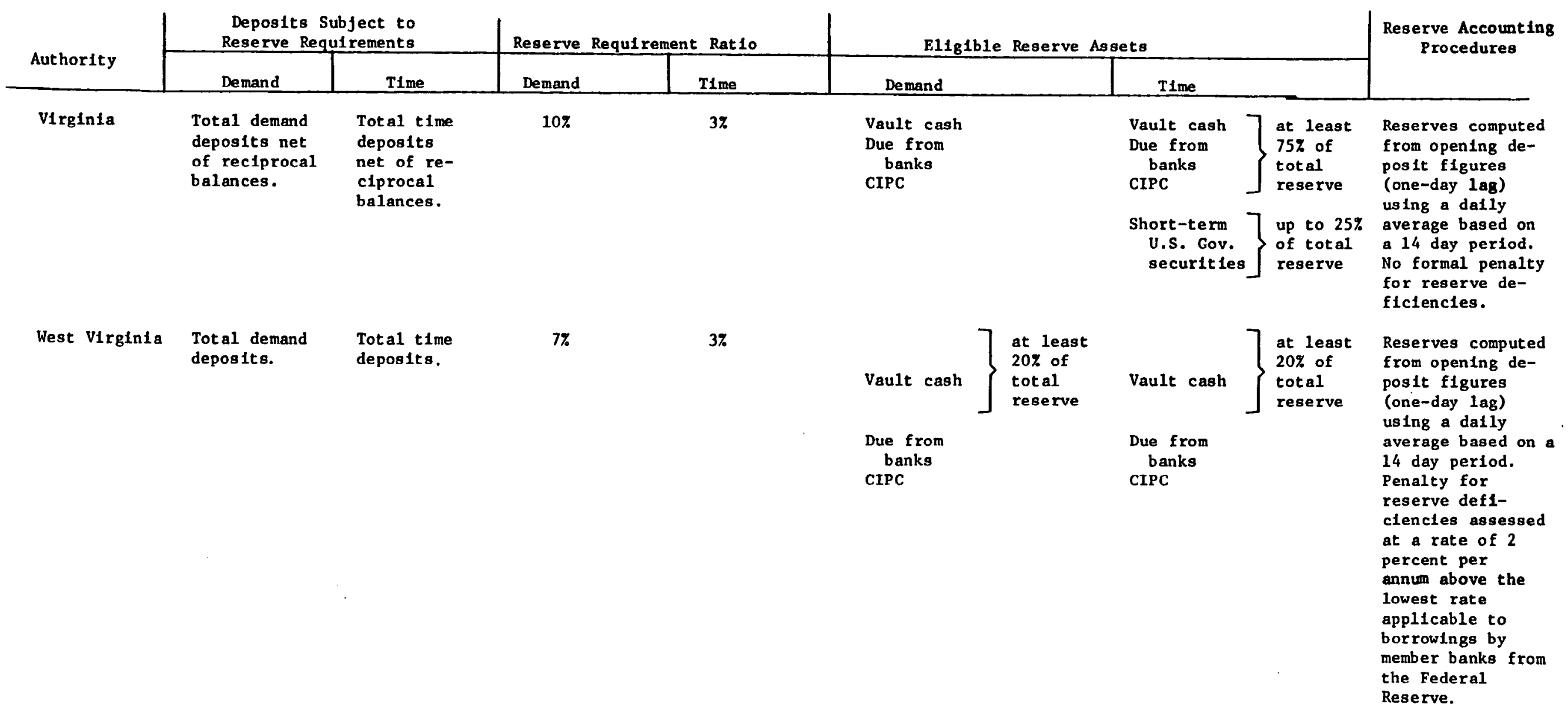


Table 1, page 3

\begin{tabular}{|c|c|c|c|c|c|c|c|}
\hline \multirow{2}{*}{ Authority } & \multicolumn{2}{|c|}{$\begin{array}{l}\text { Deposits Subject to } \\
\text { Reserve Requirements }\end{array}$} & \multicolumn{2}{|c|}{ Reserve Requil rement Rat 10 } & \multicolumn{2}{|c|}{ El1glble Reserve Assets } & \multirow[t]{2}{*}{$\begin{array}{l}\text { Reserve Accounting } \\
\text { Procedures }\end{array}$} \\
\hline & Demand & Time & Demand & Time & Demand & TIme & \\
\hline $\begin{array}{l}\text { Federal } \\
\text { Reserve } \\
\text { Systenl/ }\end{array}$ & $\begin{array}{l}\text { Total demand } \\
\text { depostts less } \\
\text { CIPC and } \\
\text { demand } \\
\text { balances due } \\
\text { from commer- } \\
\text { clal banks. }\end{array}$ & $\begin{array}{l}\text { Total time } \\
\text { deposits. }\end{array}$ & 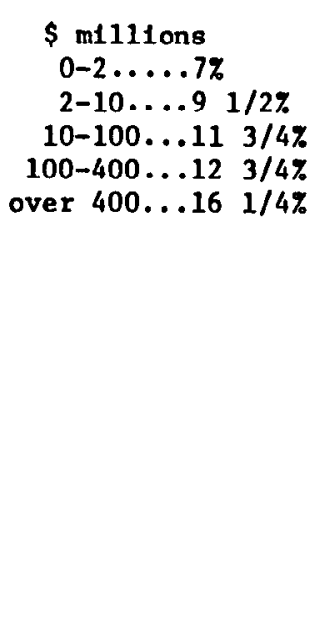 & 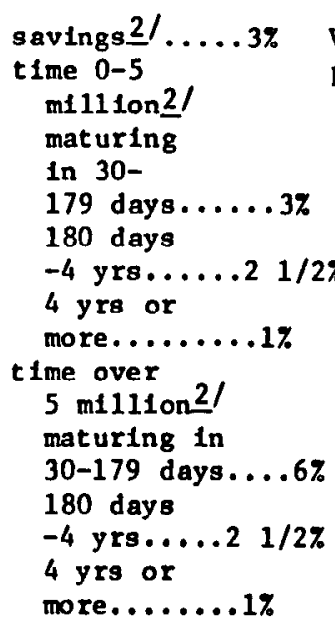 & $\begin{array}{l}\text { Vault cash } \\
\text { Deposits } \\
\text { w1th } \\
\text { F.R. Banks } \\
\%\end{array}$ & $\begin{array}{l}\text { Vault cash } \\
\text { Deposits } \\
\text { with } \\
\text { F.R. Banks }\end{array}$ & $\begin{array}{l}\text { Two-week lag using } \\
\text { a daily average } \\
\text { based on a } 7 \text { day } \\
\text { perlod. Penalty } \\
\text { for reserve de- } \\
\text { f1clencles assessed } \\
\text { at a rate of } 2 \\
\text { percent per annum } \\
\text { above the lowest rate } \\
\text { applicable to } \\
\text { borrowings by member } \\
\text { banks from the } \\
\text { Federal Reserve. }\end{array}$ \\
\hline
\end{tabular}

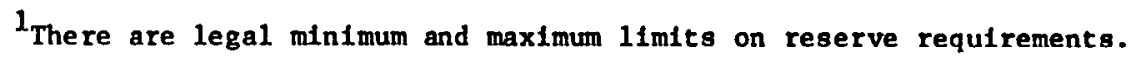

$\begin{array}{lcc}\text { Net demand: } & \text { Minimum } & \text { Maximum } \\ \text { Reserve c1ty banks } & 10 & 22 \\ \text { Other banks } & 7 & 14 \\ \text { Time } & 3 & 10\end{array}$

2 The average of reserves on savings and other time deposits must be at least 3 percent, the minimum apecified by 1 aw.

Source: Federal Reserve Bulletin, relevant statutes of the various states, and state banking departments. 
In Maryland and North Carolina, the deposit base subject to reserve requirements is net of collateralized deposits of public funds. It is assumed that all government deposits are collateralized, and the total of such deposits is therefore deducted from total deposits to arrive at a net deposit base.

Federal Reserve and North Carolina required reserve ratios on time deposits are graduated by amount held and maturity classification. Inasmuch as the Call Report does not provide deposit breakdown by maturity class, assumptions must be made as to deposit maturity structure. The July 27, 1977 Fifth District STSD is used to derive ratios showing the proportion of total tIme deposits in amounts less than $\$ 100$ thousand in specific maturity class1fications to total time deposits in amounts less than $\$ 100$ thousand. These ratios are used to calculate member bank and North Carolina nonmember bank required reserves against time deposits of less than $\$ 100$ thousand. The Jume 30, 1977 Fifth District survey of maturity distribution on weekly reporting bank negotiable $C D^{\prime} s$ is used to derive ratios showing proportions of time deposits in amounts greater than $\$ 100$ thousand in specific maturity classifications to total time deposits in amounts greater than $\$ 100$ thousand. These ratios are used to calculate member bank and North Carolina nonmember bank reserves against time deposits in amounts greater than $\$ 100$ thousand. The June 30, 1977 required nonearning asset reserves expressed as percentages of total deposits are presented in Table 2. Comparisons show that member banks' required nonearning asset reserve ratios are lower than nonmember banks' ratios in seven out of a possible twenty groups. These groups are: North Carolina, under 10 and 25-50; Virginia, under 10, 10-25, 25-50, and 50-100; and, West Virginia, under 10. An unwelghted average of the differences in member-nonmember bank ratios by size group and across states shows that member bank required nonearning asset reserve ratios are higher by $.0005, .0039$, .0032 , and .0077 , in ascending order of asset size. 
Table 2

Required Nonearning Asset Reserve as a Percent of Total Deposits

Member and Nonmember Banks by Size Group

Fifth District States

Calculated from 6-30-77 Call Report

Asget S1ze Groups, M1llions of $\$$

\begin{tabular}{|c|c|c|c|c|c|c|c|c|}
\hline \multirow[b]{2}{*}{ State } & \multicolumn{2}{|c|}{ Under 10} & \multicolumn{2}{|c|}{$10-25$} & \multicolumn{2}{|c|}{$25-50$} & \multicolumn{2}{|c|}{$50-100$} \\
\hline & Member & Nonmember & Member & Nonmember & Member & Nonmember & Member & Nonmember \\
\hline Maryland & .0413 & .0262 & .0426 & .0295 & .0454 & .0337 & .0560 & .0376 \\
\hline North Carolina & .0401 & .0428 & .0446 & .0395 & .0465 & .0487 & .0572 & .0484 \\
\hline South Carolina & .0495 & .0475 & .0511 & .0472 & .0552 & .0495 & $.0535^{1 /}$ & .0468 \\
\hline Virginia & .0387 & .0470 & .0417 & .0454 & .0428 & .0439 & .0486 & .0496 \\
\hline West Virginia & .0395 & .0429 & .0432 & .0423 & .0439 & .0419 & .0477 & .0419 \\
\hline
\end{tabular}

$1 /$ Fewer than three banks in group. 
Table 3

Adjusted Cash Assets as a Percent of Total Deposits 1/

Member and Nonmember Banks by S1ze Group

Fifth Diatrict States

Calculated from 6-30-77 Call Report

Asset Size Groups, Millions of $\$$

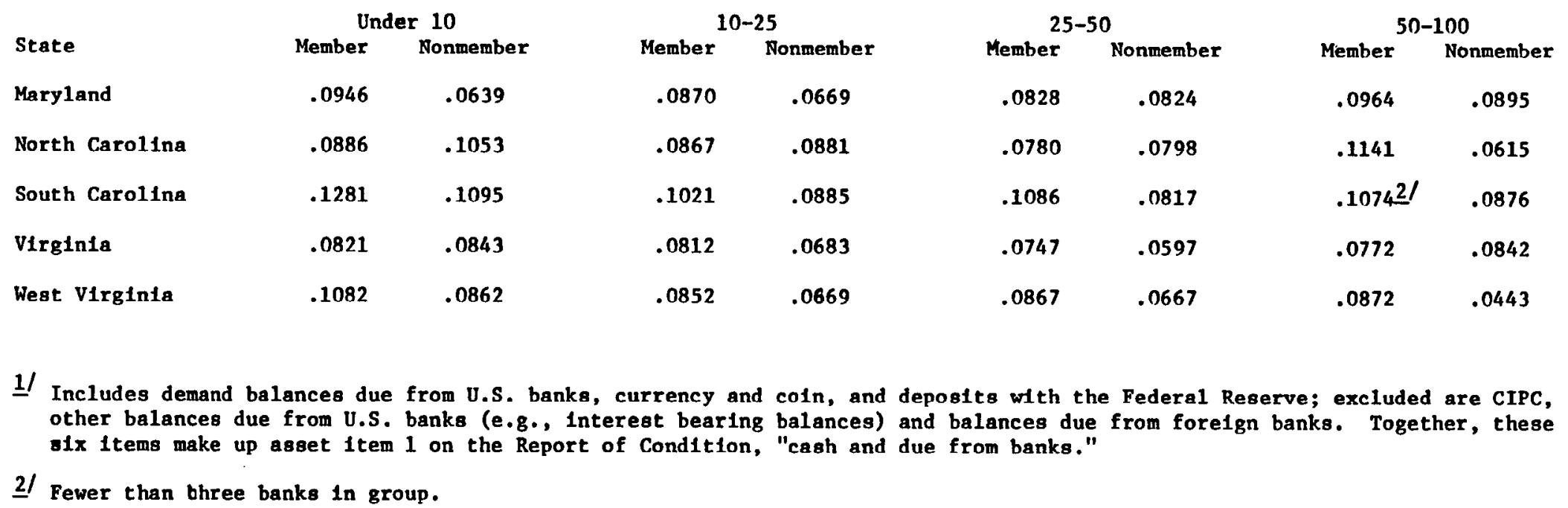


Adjusted cash asset to total deposit ratios are shown in Table 3 for the same groups discussed above. Adjusted cash assets are defined as the sum of demand balances due from U.S. banks, currency and coin, and deposits with the Federal Reserve. Member banks' ratios are lower than nonmember banks' ratios in only four of the groups (down from seven in Table 2). Using differences in member and nonmember bank adjusted cash asset ratios as the relevant measure of comparative cost of membership suggests that, for most size groups and most Fifth District states, nonmembership is less costly than membership. An unweighted average of the differences in member-nonmember bank ratios by size group and across states shows that member bank adjusted cash asset ratios are higher by $.0105, .0127, .0125$, and .0230 , in ascending order of asset size. These average differences are considerably greater than those prevalling between member and nonmember required nonearning asset reserve ratios. They suggest that, on average, Fifth District nonmember banks less than $\$ 100$ million in asset size have avallable for investment from 1.05 percent to 2.30 percent more of total deposits than do their member bank counterparts.

Regression of the actual cash asset to total deposit ratios in Table 3 on the required nonearning cash asset to total deposit ratios in Table 2 shows no significant correlation between the variables for nonmember banks. For member banks, however, this regression yields a $k^{2}$ of .23 and a significant t-statistic for the right hand variable (the required reserve to total deposit ratio). 4 These results support the idea that state reserve requirements in the Fifth District are nonbinding, while System reserve requirements are partially binding. This is consistent with the assumptions made in Section II. Thus, while differences in member and nonmember bank cash asset positions are importantly affected by System reserve requirements, other explanatory factors 
must also be considered to arrive at a complete explanation of cash asset portfolio determination.

\section{Iv. Correspondent Balances and Cash Asset Positions}

While there is little doubt that, on average, smaller member banks hold significantly more cash assets than do their nonmember counterparts, it cannot automatically be concluded that member banks must hold such excess balances. The Federal Reserve System makes available a number of correspondent type services to member and nonmember banks. These services are provided without charge to members, and therefore member bank reservable assets (vault cash and deposits held with Reserve Banks) are in some sense themselves correspondent balances. Use of System services might allow member banks to reduce their holdings of correspondent bank balances. It is likely, however, that some trade-off exists for member banks between receiving services from the Federal Reserve or from correspondent banks. This trade-off arises in cases where System services are not avallable in the quantity and/or quality demanded by member banks. It is also possible that some member banks view System services as being inaccessable, due to, for example, geographic distance from a Reserve Bank. Knight [7] notes that many small banks make 11ttle use of System services, a practice that leads to their holding higher correspondent balances. Studles based on aggregate banking data such as KnIght's, however, do not distinguish between member bank users and nonusers of System services.

Little is known about member bank utilization of System services. In fact, only two studies provide information on the utilization of System services by member banks. Gilbert [2] presents the results of a survey of 233 member banks served by the St. Louis office of the Eighth Federal Reserve District. Fifty-four of these banks, with total assets ranging from $\$ 3.4$ million to $\$ 44.5$ million, are classified by Gilbert as minimal users of System services: they clear checks with the Fed but remlt for cash letters using a correspondent's 
account, and otherwise make little use of System services. Another group of 34 banks with total assets under $\$ 50$ million are classifled as full users of system services. Weighing individual services by cost of production, Gilbert estimates that the 34 full users consume-over two times the services consumed by the average small bank. The effect of full utilization of System services on the cash asset positions of these banks is not discussed.

Hume and Russel1 [5] have surveyed the use of System services by smaller (under $\$ 100$ million deposits), medium ( $\$ 100$ million-\$2 billion deposits), and large (over $\$ 2$ billion deposits) Second District banks. Their finding is that small and medium sized bank use of System services, as calculated with a relative measure defined as Reserve Bank expenses per million dollars of member bank domestic deposits, is more than double that of large banks. This finding is not applied to the question of the comparative burden of membership, however. Inasmuch as the question of the burden of Federal Reserve membership is purely one of relative costs, it is important to consider to what extent, if any, nonmember banks have access to System services. If System services allow member banks to economize on correspondent balances, the same would hold for nonmembers to the extent that they are granted access to these services. In fact, the Federal Reserve, as part of its continuing effort to improve the national payments mechanism, has adopted a policy that extends limited payments services to nonmember banks: nonmembers are granted RCPC area clearing privileges on the same terms as are member banks, except that they must settle through a member correspondent's reserve account. Each Fifth District state is an RCPC area, an arrangement that gives nonmembers clearing privileges for all items drawn on banks in their state. Check clearing services are ranked very highly In terms of importance by respondent banks [1]. For small banks generally, intra-state clearings probably dominate their total clearings. $\underline{5}$ Therefore, nonmember bank access to RCPC's is a potentially important factor in offsetting 
the relative advantage avallable to member banks that economize on correspondent balances by using Federal Reserve clearing services.

This section of the study seeks to answer the question: what combination of membership status and System service utilization results in minimization of cash balances? Four possible combinations of membership and System service utilization are considered:

1. member fully using Fed services (MU);

2. member not fully using Fed services (MN);

3. nonmember using RCPC services (NU); and,

4. nonmember not using Fed service (NN).

Information on the use of six Federal Reserve services over the two month period December 1977-January 1978 has been collected for the universe of Fifth District member and nonmember banks operating on June 30,1977 . Adjustment for mergers and conversions out of the Federal Reserve System leaves 681 banks with total deposits less than $\$ 100$ million. Member users are defined as those member banks that clear checks in volume through the Federal Reserve and that use three additional services from the group including money transfer, security safekeeping, and wire transfer. Member nonusers are all other member banks. Nonmember users are defined as nonmember banks that direct deposit with the Federal Reserve for RCPC area clearing, while nonmember nonusers are all other nonmember banks. Table 4 is a numerical summary of banks divided into these four membership-service use combinations by size class $(\$ 0-25 \mathrm{million}$, \$25-50 milition, and $\$ 50-100$ million deposit size) and state. The size classes used in this part of the study are not as refined as those in Section III, due to the fact that division of banks by service use category results in a sharp reduction of observations for some combinations. This is particularly true for the larger size groups and for user banks, as is clear from Table 4. Mean values of adjusted cash assets to total deposits for the banks employing these four combinations, by state and within each of the three size groups, are computed. There are six possible comparisons of mean cash asset 
Table 4

Numerical Summary of Colmercial Banks by Membership-Service Use Combination

Fifth Diatrict States

Jenuary 1978

State

Maryland

North Carolina

South Carolina

virginia

West V1rginia

Total

\begin{tabular}{rrrr}
$\begin{array}{c}\text { Deposit } \\
\text { MU }\end{array}$ & \multicolumn{2}{c}{ MN } & \multicolumn{2}{c}{$0-25$} & mil110n \\
2 & 16 & 2 & 37 \\
8 & 6 & 10 & 23 \\
8 & 8 & 5 & 43 \\
20 & 68 & 2 & 76 \\
9 & 57 & 5 & 53 \\
47 & 155 & 24 & 232
\end{tabular}

\section{Deposit S1ze 25-50 mil11on}

MU MN NU NN

752

$\begin{array}{llll}5 & 1 & 7 & 5\end{array}$

$\begin{array}{llll}4 & 1 & 6 & 4\end{array}$

$\begin{array}{llll}16 & 30 & 3 & 17\end{array}$

$\begin{array}{llll}7 & 20 & 0 & 13\end{array}$

$\begin{array}{llll}39 & 57 & 18 & 51\end{array}$

\begin{tabular}{|c|c|c|c|}
\hline $\begin{array}{c}\text { Deposit } \\
\text { MU }\end{array}$ & $\begin{array}{l}\text { S1ze } \\
\text { MN }\end{array}$ & $\begin{array}{c}50-100 \\
\mathrm{NU}\end{array}$ & $\underset{\mathrm{NN}}{\mathrm{mill1}}$ \\
\hline 5 & 3 & 3 & 4 \\
\hline 1 & 1 & 4 & 1 \\
\hline 1 & 0 & 1 & 1 \\
\hline 5 & 6 & 2 & 1 \\
\hline 9 & 5 & 4 & 1 \\
\hline 21 & 15 & 14 & 8 \\
\hline
\end{tabular}

$\begin{array}{rrrr}\text { A11 } & \text { Banks } & 0-100 & \text { million } \\ \text { MU } & \text { MN } & \text { NU } & \text { NN } \\ 14 & 24 & 7 & 53 \\ 14 & 8 & 21 & 29 \\ 13 & 9 & 12 & 48 \\ 41 & 104 & 7 & 94 \\ 25 & 82 & 9 & 67 \\ 107 & 227 & 56 & 291\end{array}$


ratios based on the four membership-service we comblnations. These are:

$$
\begin{aligned}
& M_{i j}-M_{i j} ; \\
& M U_{i j}-N_{i j} ; \\
& M U_{i j}-N_{i j} ; \\
& M_{i j}-N_{i j} ; \\
& M N_{i j}-N_{i j} ; \text { and, } \\
& N_{i j}-N_{i j} ;
\end{aligned}
$$

where the first subscript, $1(1=1,2,3,4,5)$, refers to the state and the second subscript, $f(f=1,2,3)$, refers to the size group. The hypothesis that there is no significant difference between sample mems is tested using 6-statistics.6/ If the difference between sample means Is significant, the hypothesis is rejected, in which case we conclude that the membership-service use combinations being compared do have differing influences on bank cash asset positions.

Eapirical tests based on two different adjusted cash asset to total deposit ratios are evaluated. Differences in means and $t-8 t a t i s t i c s$ for ratios having demand balances due from U.S. banks, currency and coin, and deposits with the Federal Reserve in the numerator are listed in Table 5 . This is the measure of the comparative burden of membership described in Section II. Differences in means and t-statistics for ratios having the same numerator as those in Table 5, except for the addition of CIPC, are listed in Table 6. Table 6 is intended to adjust for possible overstatement in the correspondent balances of banks that clear checks through correspondent banks. Such an overstatement may be present to the extent that 
correspondent banks give immediate book credit for cash items presented for collection. These items represent uncollected funds carried on respondents' books as correspondent balances. Only collected funds, however, count toward payment for correspondent services. This adjustment is not perfect since, for member and nonmember bank users of Federal Reserve clearing services, it includes CIPC resulting from correspondent clearing activity.

\section{Maryland}

The results for Maryland are partly unexpected and somewhat unclear, problems aggravated by the small number of banks in some of the comparison groups. In general, it appears that use of System services by member banks less than $\$ 50$ million in deposit size does result in reduced cash asset ratios. The differences in mean ratios between member users and nonusers are negative for both of the smallest size groups in Tables 5 and 6 . In the $\$ 25-50$ million group in Table 5, the difference is significant at the .20 level. Differences in means for the nonmember user and nonuser comparisons have the expected negative signs: in the smallest and largest size groups for comparisons that exclude CIPC, but the t-statistics are not significant. In the middle Table 5 size group, however, nonmember users have a substantially greater mean value of cash assets to total deposits than do the nonmember nonusers. Moreover, the difference is significant at the .10 level. Differences in means for the nonmember user and nonuser comparison in Table 6 are all positive, although none is significant. These results seem surprising since nonmember users of the RCPC clearing service could reasonably be expected to economize on correspondent balances compared to their nonuser counterparts.

While use of System services by member banks less than $\$ 25$ million in deposit size does not eliminate the comparative membership burden, the evidence suggests that such use does reduce the burden. This conclusion 
Differences Between Mean Values of Adjusted Cash Asset to Total Deposit Ratios (Excluding CIPC) 1 /

Six Membership-Service Use Combinations by State and Size Group Fifth District States

Calculated From 6-30-77 Cal1 Report

Deposit S1ze Groups, Millions of $\$$

Combination

$\underline{0-25}$

$\underline{25-50}$

$50-100$

Maryland

MU - MN

$-0.0095$

$-0.0195$

$(-1.4445)$ *

0.0185

$(-0.4879)$

$-0.0498$

$(-4.3899) * * * *$

(1.2026)

MU - NU

0.0222

(0.7248)

$-0.0002$

$(-0.0132)$

0.0228

MU - NN

0.0158

$(0.8567)$

$-0.0303$

$(-1.0946)$

(1.0516)

MN - NU

0.0317

(1.5302)*

0.0193

0.0253

(1.0142)

0.0186

MN - NN

(3.2656)****

0.0496

(0.9308)

NU - NN

$-0.0064$

$(1.8183)$ **

0.0043

(0.1796)

$(-0.3413)$

0.0051

$(0.0041)$

$-0.0042$

$(-0.1467)$

North Carolina

$$
\begin{aligned}
& M U-M N \\
& -0.0127 \\
& (-1.0039) \\
& M U-N U \\
& -0.0150 \\
& (-0.8693) \\
& 0.0006 \\
& (0.0452)
\end{aligned}
$$$$
\text { 2I }
$$$$
\text { 2/ }
$$$$
-0.0029
$$$$
(-0.2196)
$$$$
\text { 21 }
$$

0.0070

$(0.4142)$

2)

2I

21

0.0099
$(0.5520)$ 
Table 5, page 2

Combination

\section{South Carolina}

\begin{tabular}{|c|c|}
\hline$M U-M N$ & $\begin{array}{l}-0.0388 \\
(-2.0936) * *\end{array}$ \\
\hline $\mathrm{MU}-\mathrm{NU}$ & $\begin{array}{c}-0.0117 \\
(-0.7821)\end{array}$ \\
\hline$M U-N N$ & $\begin{array}{c}-0.0125 \\
(-0.7912)\end{array}$ \\
\hline $\mathrm{MN}-\mathrm{NU}$ & $\begin{array}{c}0.0271 \\
(1.0741)\end{array}$ \\
\hline $\mathrm{MN}-\mathrm{NN}$ & $\begin{array}{c}0.0263 \\
(1.5463) *\end{array}$ \\
\hline $\mathrm{NU}$ - NN & $\begin{array}{l}-0.0008 \\
(-0.0387)\end{array}$ \\
\hline$M U-M N$ & $\begin{array}{l}-0.0178 \\
(-2.4043) \star \star \star\end{array}$ \\
\hline$M U-N U$ & $\begin{array}{c}0.0090 \\
(0.4385)\end{array}$ \\
\hline$M U-N N$ & $\begin{array}{l}-0.0125 \\
(-1.3220) \star\end{array}$ \\
\hline $\mathrm{MN}-\mathrm{NU}$ & $\begin{array}{c}0.0268 \\
(1.2912)\end{array}$ \\
\hline $\mathbf{M N}-\mathbf{N N}$ & $\begin{array}{c}0.0053 \\
(0.9151)\end{array}$ \\
\hline$N U$ - NN & $\begin{array}{c}-0.0215 \\
(-0.7681)\end{array}$ \\
\hline$M U-M N$ & $\begin{array}{c}-0.0090 \\
(-0.9242)\end{array}$ \\
\hline$M U$ - NU & $\begin{array}{c}0.0095 \\
(0.5740)\end{array}$ \\
\hline
\end{tabular}

2]

0.0381

$(2.6987) * \star *$

$-0.0111$

$(-0.6433)$

2/

$2 /$

$-0.0492$

$(-3.8456) * * \star *$

\section{Virginia}

$-0.0106$

$(-1.3834)$ *

0.0166

(1. 4321$)$ *

$-0.0078$

$(-0.3958)$

$-0.0311$

$(-1.0802)$

0.0091

$(0.9759)$

2I

0.0028

$(0.2273)$

0.0197

(3.1625)****

0.0169

(1.2264)

$-0.0477$

$(-2.1221)$ **

21

21

West Virginia

$-0.0161$

$(-1.2416)$

2)
0.0031

(0.2485)

0.0431

(3. 2370)**** 
Table 5, page 3

Combination

$\underline{0-25}$

0.0066

$(0.6244)$

$\mathrm{MN}-\mathrm{NU}$

0.0185

$(1.5336) *$

MN - NN

$\mathrm{NU}-\mathrm{NN}$
0.0156

$(2.9858) * \star \star *$

$-0.0029$

$(-0.2236)$
25-50

50-100

West Virginia

0.0124

$(1.4747)$ *

2/

0.0400

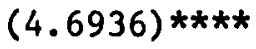

0.0285

$(2.8745) * * * \star$

2I

21

21

$1 /$ Numerators of ratios exclude CIPC. t-statistics are in parentheses.

$2 /$ Number of observations in at least one group less than two. *significant at the .20 level

**stgnificant at the .10 level

***significant at the .05 level

$\star * \star \star s i g n i f i c a n t$ at the .01 level 
Table 6

Differences Between Mean Values of Adjusted Cash Asset to Total Deposit Ratios (Including CIPC) 1/

Six Membership-Service Use Combinations by State and Size Group Fifth District States

Calculated From 6-30-77 Call Report

Deposit Size Groups, Millions of $\$$

Combination

$\underline{0-25}$

$25-50$

$\underline{50-100}$

Maryland

MU - MN

$-0.0122$

$-0.0097$

0.0199

$(-0.5949)$

$(-0.6863)$

$(1.6166)$ *

MU - NU

0.0004

$-0.0402$

0.0153

$(0.0270)$

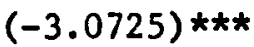

$(0.8916)$

MU - NN

0.0146

0.0005

0.0282

$(0.8015)$

$(0.0292)$

$(1.6037) *$

MN - NU

0.0126

$-0.0305$

$-0.0046$

$(0.6151)$

$(-1.1007)$

$(-0.1906)$

$\mathrm{MN}-\mathrm{NN}$

0.0268

0.0102

0.0083

(3.4284)****

$(0.4440)$

$(0.3461)$

NU - NN

0.0142

0.0407

0.0129

$(0.7843)$

(1.1952)

$(0.4656)$

\section{North Carolina}

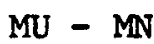

0.0181

$(0.8793)$

2/

2/

MU - NU

0.0188

$(0.9555)$

$-0.0028$

$(-0.2470)$

2/

MU - NN

0.0257

0.0033

$(1.8736) * \star$

$(0.2167)$

21

MN - NU

0.0006

21

21

$(0.0364)$

21

MN - NN

0.0076

(0.5318)

0.0061

$\mathrm{NU}-\mathrm{NN}$

0.0070

$(0.3965)$

21 
Table 6 , page 2

Combination

\section{South Carolina}

\begin{tabular}{|c|c|}
\hline $\mathbf{M U}-\mathbf{M N}$ & $\begin{array}{c}-0.0301 \\
(-1.6515) *\end{array}$ \\
\hline$M U-N U$ & $\begin{array}{c}-0.0055 \\
(-0.3858)\end{array}$ \\
\hline $\mathrm{MU}-\mathrm{NN}$ & $\begin{array}{c}-0.0061 \\
(-0.3850)\end{array}$ \\
\hline$M \mathbb{N}-N U$ & $\begin{array}{c}0.0246 \\
(1.0212)\end{array}$ \\
\hline $\mathbf{M N}-\mathbf{N N}$ & $\begin{array}{l}0.0240 \\
(1.4169) *\end{array}$ \\
\hline$N U-N N$ & $\begin{array}{l}-0.0006 \\
(-0.0301)\end{array}$ \\
\hline
\end{tabular}

21

0.0432

$(2.9287) * * *$

$-0.0013$

$(-0.0741)$

2/

21

$-0.0445$

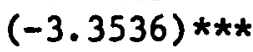

\section{Virginia}

MU - MN

0.0065

$(0.9426)$

$\mathrm{MU}-\mathrm{NU}$

0.0303

$(0.9531)$

MU - NN

0.0163

(1.6456)*

$\mathrm{MN}-\mathrm{NU}$

0.0238

(1.1087)

$\mathrm{MN}-\mathrm{NN}$

NU - NN

0.0098

$(1.7074) * *$

$-0.0140$

$(-0.5121)$

MU - MN

$-0.0031$

$(-0.3232)$

MU - NU
0.0149

$(0.9952)$
0.0002

$(0.0187)$

0.0107

$(0.5062)$

0.0254

(2.5875)***

0.0105

$(0.7374)$

0.0252

(1.1232)

0.0147

(1.0970)

0.0306

(3.5698)****

$-0.0124$

$(-0.4958)$

21

$-0.0430$

$(-1.9127)$ *

21

2/

\section{West Virginia}

$-0.0174$

$(-1.1363)$

0.0108

$(0.8676)$

21
0.0459

(3.5699) **** 
Table 6 , page 3

Combination

$\underline{0-25}$

0.0113

(1.0252)

$\mathbb{N}$ - NU

MN - NN

$\mathrm{NU}-\mathrm{NN}$
0.0180

$$
\text { (1.4847) }
$$

$$
0.0144
$$$$
(2.6458) * * * *
$$

$-0.0036$

$(-0.2515)$
25-50

$50-100$

West Virginia

$$
\begin{gathered}
0.0140 \\
(1.6749) *
\end{gathered}
$$

21

0.0351

$(4.2777) * * * *$

0.0314

$(2.6791) * * *$

$2 /$

2)

$\underline{1}$ Numerators of ratios include CIPC. t-statistics are in parentheses.

$2 /$ Number of observations in at least one group less than two.

*significant at the .20 level

** significant at the .10 level

$* * \star$ significant at the .05 level

**** significant at the .01 level 
holds for comparisons either including or excluding CIPC. For member user banks in the \$25-50 million deposit range, there does not appear to be a burden to membership; the difference with nonmember users is negative, large, and significant, while the difference with nonmember nonusers is not significantly different from zero. This conclusion is supported by the results in Tables 5 and 6 .

\section{North Carolina}

Tables 5 and 6 show conflicting results for the smallest category of North Carolina banks. Comparisons that exclude CIPC indicate that membership in the Federal Reserve entails no burden and may lead to economies in cash asset management. This suggested result in Table 5 is consistent with the evidence in Table 3. Member users of System services have a lower mean cash asset ratio than do member nonusers. This results in much larger favorable differentials for member users compared to nonmember banks than for member nonusers compared to nonmember banks. None of these differences, however, is statistically significant. The difference in mean cash asset ratios between nonmember user and nonuser banks is not significantly different from zero in either of the two size groups where comparisons are made.

Table 6, which includes CIPC in the computation of cash asset ratios, shows that the smallest category of member banks using System services has a mean cash asset ratio higher than that of member nonusers. The small member user banks have a much higher mean ratio of CIPC to total deposits than do the small member nonusers: the CIPC to total deposit ratios of these two groups are .0413 and .0104 , respectively. It is difficult to explain the unusually high member user CIPC ratio except in terms of high dollar volume of clearing activity. I/ As in Table 5, the difference in mean cash asset ratios between nonmember user and nonuser banks is not significantly different from zero for either of the two smallest size groups. 
Further ratio comparisons cannot be made because of the lack of observations in the remaining membership service-use combinations. It is Interesting to note, however, as shown in Table 4, that four out of five nonmember banks in the $\$ 50-100$ million deposit size range use the RCPC area clearing service.

\section{South Carolina}

The evidence for South Carolina indicates that utilization of System services by smaller member banks leads to a substantial reduction in cash asset ratios. The results in Tables 5 and 6 are consistent, although in Table 6 the advantage held by member users of system services is not as great as that shown in Table 5 .

The difference in means for member users and nonusers in the $\$ 0-25$ million size group in Table 5 is -.0388 and is significant at the .10 level. Service use has important Implications for the membership question, inasmuch as member users reverse the burden experienced by member nonusers. Use of the RCPC service allows nonmember banks in the middle size group to maintain a mean cash asset ratio .0492 lower than that of the nonmember nonusers. In the smallest size group, however, use of the RCPC service does not lead to any significant difference in nonmember bank cash ratios.

For the $\$ 25-50$ million deposit group in Table 5, the negative sign of the difference in means for member users and nonmember nonusers suggests that utilization of System services can eliminate membership burdens. However, the results also show that the relative burden of membership is restored when comparison is made with nonmember banks that also use System services.

\section{$\underline{\text { Virginia }}$}

The results for Virginia in Table 5 show that member bank users of System services in the two smallest size groups maintain substantially lower 
cash asset ratios than do member nonusers. This result is reversed in the \$50-100 million deposit category. Comparisons using ratios with CIPC yield the opposite result in the $\$ 0-25$ million deposit size group: member users have a higher mean cash asset ratio than do nonusers, although this difference is not statistically significant. The smallest Virginia member user banks, like the smallest North Carolina member users, have high CIPC to total deposit ratios. Virginia member users $\$ 0-25$ million in deposit size have a mean CIPC to total deposit ratio of .0320 , compared to .0078 for member nonusers. Table 6 shows no significant difference in means for member users and nonusers of System services in the middle size group, while the results in the $\$ 50-100$ million deposit group are basically consistent with those in Table 5.

Tables 5 and 6 show consistent results for comparisons between nonmember users and nonusers. Nevertheless, the results are confused, the differences being negative for the smallest group but positive for the middle group.

\section{West Virginia}

In West Virginia, the evidence in Tables 5 and 6 suggests that use of System services allows member user banks less than $\$ 50 \mathrm{million}$ in deposit size to reduce cash asset ratios compared to member nonusers, while in the largest size group there is no such reduction. The results in Table 5, however, show a somewhat greater advantage for member users in the two smallest groups, and a somewhat smaller disadvantage in the largest group. For nonmember banks in the smallest deposit size group, use of the RCPC area clearing service seems to have little effect on cash asset ratios. In the smallest size group in Table 5, use of System services allows member banks to roughly equate their cash ratios with those of nonmember banks. Member nonusers, however, maintain significantly greater cash asset ratios than do nonmembers. 
In the middle size category in Table 5, use of System services allows member banks to cut the membership burden by more than half: member users have a mean cash asset ratio .0124 larger than that for the nonmember nonusers, while member nonusers have a cash asset ratio .0285 greater than that of the nonmember nonusers. The burden is approximately halved for the middle group In Table 6 , as well. In the $\$ 50-100$ million size category in Tables 5 and 6 , member users and nonusers have mean cash asset ratios from .0351 to .0459 greater than those of the nonmember user groups.

\section{Fifth District Summary}

The empirical evidence in Table 5 strongly supports the idea that use of System services by member banks less than $\$ 50$ million in deposit size is associated with cash balance economization. For member banks in the $\$ 0-25$ milion deposit classification, System service use results in reduction of the membership burden in one state (Maryland), elimination of the burden in two states (South Carolina and West V1rginia), reversal of the burden in one state (Virginia), and enhancement of an already advantageous position in another state (North Carolina) when comparison is made with nonmember nonusers of the RCPC area clearing service. The results from comparison between nonmember users and nonusers of the RCPC service are unclear, although in four states (Maryland, South Carolina, Virginia, and West Virginta) there is some indication that nonmember users may be able to achieve cash economies. To the extent that this is the case, the relative gains made by member banks in cash balance economization through use of System services are moderated.

For member banks in the \$25-50 million deposit classification, System service use results in reduction of the membership burden in two states (Virginia and West Virginia) when comparison is made with nonmember nonusers. This result is also suggested in Maryland, although without the same degree of significance. 
A small number of observations prevents as complete an analysis for North Carolina and South Carolina. However, using Tables 3 and 5 together leads to the tentative conclusion that there is no reduction of the burden in North Carolina and a possibly large reduction in South Carolina. In one state (South Carolina), nonmember users of the RCPC service have a mean cash asset rat lo significantly smaller than that of nonmember nonusers. In three other states where this comparison is made, however, there is no such reduction. While the evidence suggests that South Carolina member users experience no burden compared to nonmember nonusers, the relative burden is substantial and significant when the comparison is made with nonmember users of the RCPC area clearing service.

Few results are available for banks in the $\$ 50-100$ million deposit classification due to the small number of observations. Available evidence supports the idea, however, that member users of System services maintain greater cash asset ratios than do member nonusers.

This evidence, which is based on comparisons of mean cash asset ratios that exclude CIPC, is not completely consistent with evidence based on cash asset ratios that include CIPC. For member banks \$0-25 million in deposit size, the results in Table 6 support those in Table 5 showing a reduction of the membership burden in Maryland and elimination of the burden in South Carolina Table 6 shows a reduction of the burden in West Virginia. In North Carolina and Virginia, Table 6 shows larger mean cash asset ratios for the smallest member users than for the smallest member nonusers. This is due to the large CIPC ratios maintained by these member user groups. If these high ratios result from a high dollar volume of clearing activity, then these banks should not be considered disadvantaged compared to member nonusers. This explanation needs to be tested. 
The results from comparison of $\$ 25-50$ million deposit member user and nonuser mean cash asset ratios that include CIPC are about the same as the results based on ratios that exclude CIPC. An exception, however, is Virginia: no reduction in the membership burden is apparent when CIPC is included in the analysis of $\$ 25-50$ million deposit sized banks. The evidence from Tables 5 and 6 is consistent for banks above $\$ 50$ million in deposit size: member users of System services maintain higher cash asset ratios than do member nonusers. When CIPC is included, however, the member user ratios are even higher. This combined evidence suggests that member user banks above $\$ 50$ million in deposit size are acting as correspondents. Moreover, it suggests that the $\$ 50$ million deposit size level marks the beginning of a different class of bank insofar as type of operations and demand for correspondent services are concerned. For example, use of System services by member banks in the \$50-100 million size range may be assoclated with other forms of banking activity that give rise to increased demands for correspondent services. Member users might be more aggressive in making loans, for instance, leading to demand for loan participations with correspondent banks. This is an important correspondent service that the Federal Reserve does not offer. Further research is necessary to test this explanation.

Computing the Relative Return on Member Bank Reserves

In Section II, a formula for measuring the service retum on member bank reserve balances compared to correspondent balances was developed. This coefficlent of relative retum is computed for member bank users of System services by state and deposit size class in Table 7. An assumption made in Section II is that member bank vault cash ratios are equal to or greater than nonmember bank ratios. This is true, however, in only eight of the fifteen 
Table 7

Coefficient of Relative Return on Units of Member

Bank Reserve Assets Compared to Units of

Correspondent Bank Balances 1 /

Fifth District States by Deposit Size Group

Deposit Size Groups, Millions of $\$$

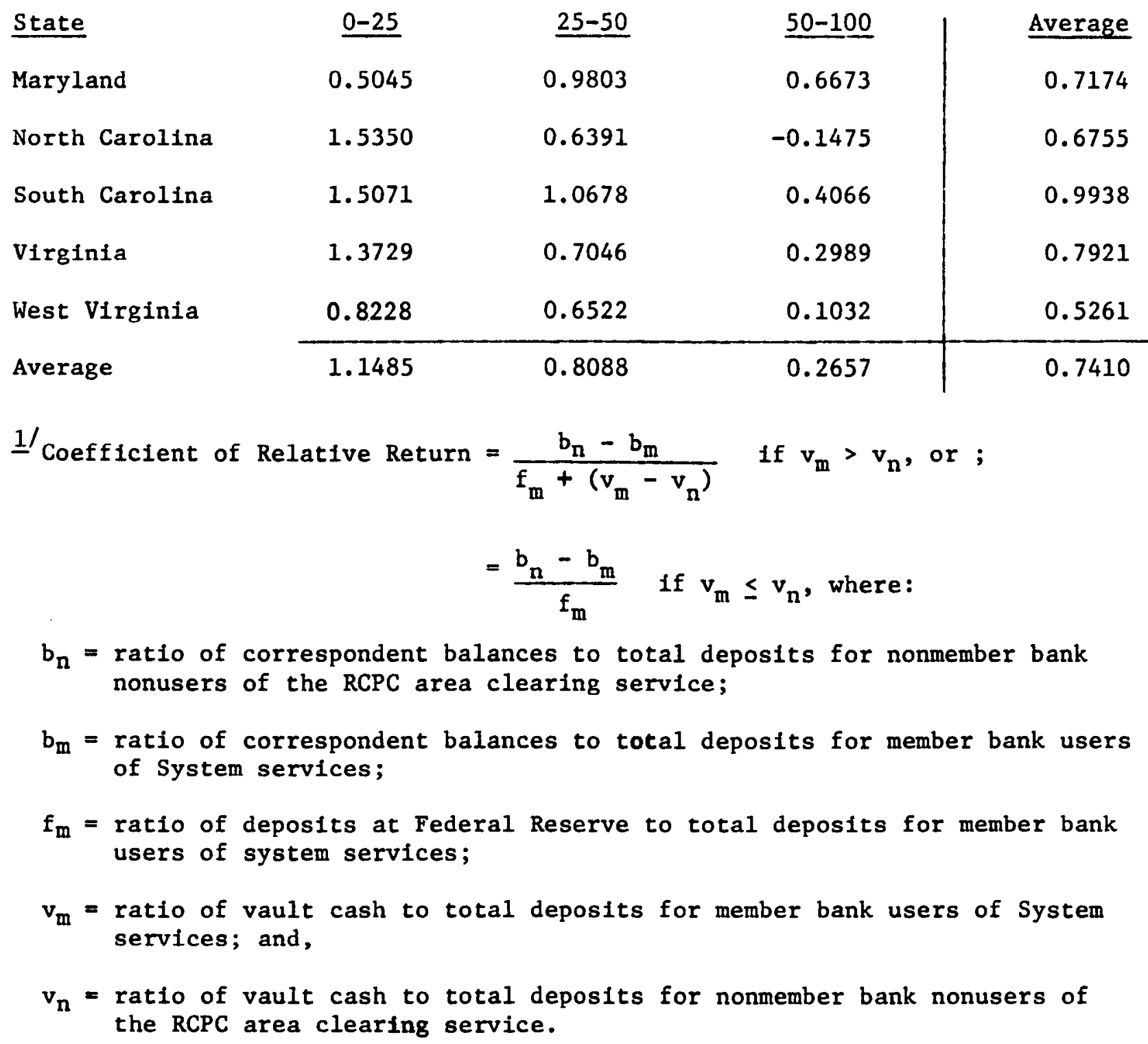


cases considered in Table 7. $/$ In cases where the assumption holds, the coefficient is computed using the formula described in Section II. In the other seven cases, however, the denominator is adjusted to include only member bank deposits with Reserve Banks. This adjustment yields lower coefficients than would result if the original formula were used.

The numerators of the ratios in Table 7 are computed using book values of nonmember nonuser and member user correspondent balances; collected balances are unknown. The magnitudes of the coefficients are distorted to the degree that book balances and collected balances differ. If member banks clearing checks directly with the Federal Reserve have higher proportions of collected balances to correspondent book balances than do nonmembers clearing with correspondents, then these ratios are overstated. The ordinal rank of these coefficients is probably more meaningful than their specific values.

The results in Table 7 indicate an inverse relationship between bank size and service yield on member bank reserves. Whereas the smallest member banks realize a return equal to 1.1485 times that earned by nonmembers on correspondent balances, the larger member banks realize a return considerably less than that earned by nonmembers on correspondent balances. These results are in keeping with those presented above, which show that the smallest member banks are in many cases able to achieve cash economies by using System services. Larger member banks are required to maintain higher ratios of required reserves than smaller banks, and it is possible that System services satisfy a smaller fraction of the larger member banks' total demand for correspondent type services. Both of these factors would work to lower the larger bank coefficients shown in Table 7.

The variation in coefficients among states is less than that among deposit size groups. Nevertheless, there are still considerable differences. Member banks in South Carolina realize a yield on their reserve balances ap- 
proximately equal to that realized by nonmembers on correspondent balances. The relative return is lower but still high for Virginia, Maryland, and North Carolina member banks. In West Virginia, the relative return on member bank reserve balances is only about half that realized by nonmembers on correspondent balances.

These results indicate that Federal Reserve System services are generally competitive with correspondent services for banks less than $\$ 50$ m111ion in deposit size. For larger member banks, however, the proportion of assets that must be held in nonearning required reserves rises while demand for a wider varlety of services probably increases. As a result, the larger banks earn on reserve assets only a fraction of what nonmembers earn on correspondent balances.

Analysis of the results by state suggests that there may be regional differences in the demand for and/or avallabllity of Federal Reserve services by and to member banks. In South Carolina, where member banks have required nonearning asset ratios that are the highest in the District (see Table 2), the coefficient of relative return is nonetheless the highest among the District states. In West Virginia, where member banks have required nonearning asset ratios that are in the low range among the District states (see Table 2), the coefficlent of relative return is nonetheless the lowest. Thus, for South Carolina banks, System services must satisfy a large portion of bank service demands. In West Virginia, on the other hand, the services offered by the Federal Reserve either incompletely satisfy bank demands or are limited in availability.

\section{v. Conclusion}

Legal reserve requirements, even when used to calculate actual nonearning assets required, give an incomplete plcture of the costs of membership compared to the nonmembership alternative. A more appropriate measure 
of the comparative costs of membership and nonmembership is the array of cash assets including deposits with Reserve Banks, demand balances with correspondent banks, vault cash, and possibly CIPC.

Analysis by state and bank size group indicates that Fifth District member banks under $\$ 100 \mathrm{million}$ in deposit size generally maintain higher ratios of cash assets to deposits than do nonmember banks. However, use of Federal Reserve System services by Maryland, South Carolina, and West Virginia member banks less than $\$ 50$ million in deposit size results in reduction or elimination of this relative burden when comparison is made to nonmember nonusers of the RCPC area clearing service. The relative gains made by member users are moderated when comparison is made to nonmember users. Small North Carolina and Virginia member user banks have higher cash asset ratios than member nonusers and all nonmembers when CIPC is included in the calculations. These small member user banks may have high dollar volumes of clearings, and some may be offering correspondent clearing services.

Available evidence suggests that among member banks greater than $\$ 50$ million in deposit size, users of System services maintain higher cash asset ratios than do nonusers.

A ratio measuring the relative return on units of member bank reserve assets to units of correspondent bank balances can be computed using data on member bank reserve assets and due from balances, and nonmember bank vault cash and due from balances. This ratio, called the coefficient of relative return, is inversely related to bank size. Units of reserve assets have a high relative service yield for member banks less than $\$ 50$ million in deposit size but a low relative service yield for larger banks. The value of this coefficient varies considerably between states, suggesting that the demand for and/or availability of Federal Reserve System services is regionally uneven. 
The empirical results presented in this study support the conclusion that Federal Reserve System services represent a powerful tool for attracting and keeping member banks less than $\$ 50$ million in deposit size. All member banks pay for these services by virtue of holding required reserves. However, fewer than one-third of the smaller member banks fully utilize such services. Among the smaller member banks in the Fifth Federal Reserve District, it is primarily the nonusers of System services that suffer a burden of membership. 


\section{Footnotes}

1. The five states are Maryland, North Carolina, South Carolina, Virginia, and West Virginia. Washington, D.C. is excluded from the study since all District of Columbia banks must follow the reserve requirements applicable to member banks.

2. Of course, banks also have CIPC. Some correspondent banks grant immediate book credit for cash items presented for clearing, a practice that acts to depress respondent bank CIPC and to inflate due from balances. Federal Reserve Banks grant book credit only for collected cash items. Consequently, CIPC may be lower, and due from balances higher, for banks clearing through correspondents than for banks clearing through Reserve Banks. CIPC might also be relatively high for those users of Federal Reserve clearing services that act as correspondent banks.

This theoretical framework abstracts from CIPC because of the difficulty involved in interpreting the factors mentioned above. CIPC is considered in the empirical tests described in Section IV.

3. Use of Federal Reserve cost data for purposes of ranking member banks by degree of reliance on System services, however, does seem appropriate. Hume and Russel1 [5] follow this approach in analyzing the probable effects introduction of a pricing policy would have on Second District member banks of various sizes.

4. The regression results are:

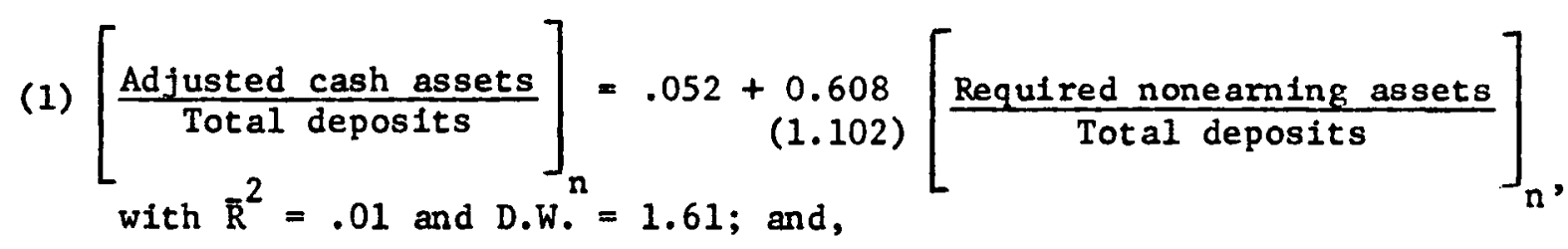

(2) $\left[\begin{array}{l}\frac{\text { Adjusted cash assets }}{\text { Total deposits }} \\ \text { with } \overline{\mathrm{R}}^{2}=.23 \text { and } \mathrm{D} . \mathrm{W}^{\mathrm{m}}=1.80 .\end{array}=.032+\frac{1.316}{(2.629)}\right.$

5. Daily average volume of regular items cleared by Fifth District nonmember direct depositing banks under $\$ 100$ million in asset size exceeds that of direct depositing member banks during a one month sample period by 30 percent. This evidence supports the idea that the greatest part of check volume for smaller banks represents local and regional items. It also suggests that the smaller nonmember banks actually using Federal Reserve clearing facilities do so more intensively than smaller member users.

6. The statistic $t=\left(D-\Delta_{H}\right) / S_{D}$, where $D$ is the difference between the two sample means; $\Delta_{H}$ is the hypothetical difference between sample means, or zero; and $S_{D}$ is the estimated standard error of the difference between the two means. 
7. Among Fifth District member user banks less than $\$ 25$ million in deposit size, those in North Carolina have the highest volume of regular items cleared during a one month sample period. The daily average volume for North Carolina banks is 1,697 items compared to an average of 1,126 for the other four states.

8. The unweighted mean value of the eight cases where member user cash asset ratios are larger is .0042 . The absolute value of the unweighted mean of the seven cases where member user cash asset ratios are smaller is .0027 . 


\section{References}

1. Clark, John S. "New Study Shows Where Correspondent Banking Stands, Where It's Headed." Banking, (November 1976), pp. $42 \mathrm{f}$.

2. Gilbert, R. Alton. "Utilization of Federal Reserve Bank Services by Member Banks: Implications for the Costs and Benefits of Membership," Review, Federal Reserve Bank of St. Louls, (August 1977), pp. 2-15.

3. Gilbert, Gary G. and Manferd 0. Peterson. "Reserve Requirements, Federal Reserve Membership and Bank Performance." Federal Deposit Insurance Corporation, Working Paper 74-8.

4. "The Impact of Changes in Federal Reserve Membership on Commercial Bank Performance." Journal of Finance, (June 1975), pp. 713719.

5. Hume, Susan R. and Katherine S. Russel1. "A Study of the Relative Usage of Federal Reserve Services by Member Banks in the Second Federal Reserve District." Federal Reserve Bank of New York, Banking Studies Division, January 25, 1978.

6. Goldberg, Lawrence G. and John T. Rose. "Do State Reserve Requirements Matter?" Journal of Bank Research, (Spring 1977), pp. 31-39.

7. Knight, Robert E. "Comparative Burdens of Federal Reserve Member and Nonmember Banks." Monthly Review, Federal Reserve Bank of Kansas City, (March 1977), pp. 13-28.

8. Quick, Perry D. Appendix A to "The Burden of Federal Reserve Membership, NOW Accounts, and the Payment of Interest on Reserves," by the staff of the Board of Governors of the Federal Reserve System. Mimeographed, Board of Governors of the Federal Reserve System, June 1977.

9. Varvel, Walter A. "The Cost of Membership in the Federal Reserve System." Federal Reserve Bank of RIchmond, Working Paper 77-1, March 1977. 


\section{Appendix A}

A criticism frequently leveled against cross-section studies of bank portfolio behavior that use Call Report data is that single day figures do not necessarily reflect the actual condition of bank statements averaged over longer time perlods. This study relies heavily on Call Report data, as do most other studies of the membership question; the Call Report is the only source of comparable data for member and nonmember banks. The appropriateness of using Call Report data as a proxy for the behavior of bank cash assets over longer time periods is examined in this appendix.

Commerclal banks report total cash and due from banks for the close of business as Call Report asset item 1. This figure includes the total of: CIPC; demand balances due from domestic banks; other balances due from domestic banks, Including interest bearing balances; balances due from foreign banks; currency and coin; and deposit balances held with the Federal Reserve. The total of these six items is also reported, however, as an average for the 15 or 30 calendar days ending with the call date. This figure appears in memorandum item 1. Comparison of asset item 1 with memorandum item 1 , therefore, will show if the call data for total cash assets closely approximates the daily average of such assets for the month of the call. Such a comparison is made below for June 30, 1977 and the daily average of the period June 1977.

Table Al shows differences in mean values of total cash asset to total deposit ratios for the universe of Fifth District member and nonmember banks divided by deposit size group. For member banks, the differences between the daily figures and the daily average figures range from .0041 in the smallest size group to -.0021 in the largest size group. For nonmember banks, the differences range from .0025 in the smallest size group to .0085 in the largest size group. The basic question is, are these differences in means due to chance 
variation or to fundamental differences in the single day data and the daily average data? The hypothesis that there is no significant difference between means is tested using t-tests. t-statistics are computed using the procedure defined in footnote 6 . These t-statistics, which are shown in parentheses in Table Al, indicate that in five of the six cases tested, the variation in means is too small for us to conclude that the comparison means represent different sets of data. For nonmember banks in the $\$ 25-50$ million deposit size classification, the difference is significant at the .20 level.

The hypothesis that there is no significant difference between June 30 , 1977 data and June 1977 daily average data is accepted for all three groups of member banks and two out of three groups of nonmember banks. The Call Report cash asset to total deposit ratios are concluded to be generally representative of bank cash asset behavior over monthly periods prior to the mid-year call date. 


\section{Differences Between Mean Values of Total}

Cash Asset to Total Deposit Ratios 1 )

June 30, 1977 Call Date and June 1977 Daily Average Data

Fifth District Banks by Size and Membership Class

Deposit Size

Militons of $\$$

$0-25$

$25-50$

$50-100$
Member Banks

0.0041

$(1.0208)$

0.0025

$(0.6401)$

$-0.0021$

$(-0.1709)$
Nonmember Banks

0.0025

$(0.6822)$

0.0079

(1. 3283)*

0.0085

$(0.7868)$

$1 /$ t-statistics in parentheses.

*significant at the .20 level 